\title{
Rumen Fermentation and Intestinal Supply of Nutrients in Dairy Cows Fed Rumen-Protected Soy Products
}

\author{
I. R. Ipharraguerre, ${ }^{1}$ J. H. Clark, ${ }^{1}$ and D. E. Freeman ${ }^{2}$ \\ ${ }^{1}$ Department of Animal Sciences and \\ ${ }^{2}$ Department of Veterinary Clinical Medicine, University of Illinois, Urbana 61801
}

\begin{abstract}
Four multiparous lactating Holstein cows that were fistulated in the rumen and duodenum and that averaged $205 \mathrm{~d}$ in milk were used in a $4 \times 4$ Latin square design to evaluate the practical replacement of solventextracted soybean meal (SSBM) with soy protein products of reduced ruminal degradability. On a dry matter (DM) basis, diets contained $15 \%$ alfalfa silage, $25 \%$ corn silage, 34.3 to $36.9 \%$ corn grain, $19.4 \%$ soy products, $18.2 \%$ crude protein, $25.5 \%$ neutral detergent fiber, and $35.3 \%$ starch. In the experimental diets, SSBM was replaced with expeller soybean meal (ESBM); heated, xylose-treated soybean meal (NSBM); or whole roasted soybeans (WRSB) to supply $10.2 \%$ of the dietary DM. Intakes of DM (mean $=20.4 \mathrm{~kg} / \mathrm{d})$, organic matter, and starch were unaffected by the source of soy protein. Similarly, true ruminal fermentation of organic matter and apparent digestion of starch in the rumen and total tract were not altered by treatments. Intake of $\mathrm{N}$ ranged from 567 (WRSB) to $622 \mathrm{~g} / \mathrm{d}$ (ESBM), but differences among soy protein supplements were not significant. Compared with SSBM, the ruminal outflow of nonammonia N was higher for NSBM, tended to be higher for ESBM, and was similar for WRSB. The intestinal supply of nonammonia nonmicrobial $\mathrm{N}$ was higher for NSBM and WRSB and tended to be higher for ESBM than for SSBM. However, no differences were detected among treatments when the flow to the duodenum of nonammonia nonmicrobial $\mathrm{N}$ was expressed as a percentage of $\mathrm{N}$ intake or nonammonia $\mathrm{N}$ flow. The ruminal outflow of microbial N, Met, and Lys was not altered by the source of soy protein. Data suggest that partially replacing SSBM with ESBM, NSBM, or WRSB may increase the quantity of feed protein that reaches the small intestines of dairy cows. However, significant improvements in the supply of previously reported limiting amino acids for milk production, particularly of Met, should not be expected.
\end{abstract}

Received October 20, 2004.

Accepted April 5, 2005.

Corresponding author: I. R. Ipharraguerre; e-mail: ipharrag@ uiuc.edu.
(Key words: rumen-protected soy product, ruminal fermentation, intestinal supply of nutrients, dairy cow)

Abbreviation key: ESBM = expeller soybean meal; EAA = essential amino acids; NANMN = nonammonia nonmicrobial nitrogen; NEAA = nonessential amino acids; NSBM = heated, xylose-treated soybean meal; SSBM = solvent-extracted soybean meal; WRSB = whole roasted soybeans.

\section{INTRODUCTION}

Under conventional feeding conditions, an inadequate amount or pattern of essential amino acids (EAA) absorbed from the small intestine of dairy cows, particularly of Met, Lys, and His (NRC, 2001), may be partly responsible for creating or aggravating inefficiencies in the postabsorptive metabolism of $\mathrm{N}$ (Lobley, 2002). Selection of the proper source of supplemental CP for feeding offers an excellent opportunity for influencing the supply of AA to dairy cows. This is because the CP source modulates the intestinal supply of AA by affecting the passage of RUP and microbial $\mathrm{N}$ to the lower gastrointestinal tract (Clark et al., 1992). In addition, the contribution of RUP to the ruminal outflow of total protein and its AA composition impact the pattern of AA available for absorption in the small intestine (Rulquin and Vérité, 1993; NRC, 2001).

Solvent-extracted soybean meal (SSBM) and raw soybeans are excellent sources of RDP that can be used to supply ruminal microorganisms with the forms of $\mathrm{N}$ required for driving their growth (Stern et al., 1985; Tice et al., 1993). Although soy proteins are a good source of digestible Lys and His (Santos et al., 1998; NRC, 2001), they are low in Met (1.44 to $1.47 \%$ of CP) and can be extensively degraded ( $\geq 57.4$ to $69.6 \%$ ) by ruminal microbes (NRC, 2001), which may compromise their value for contributing quantitatively and (or) qualitatively to the supply of EAA in metabolizable protein. This limitation motivated the development of several methods for decreasing the ruminal degradability of proteins in SSBM and soybean seeds. Some of the most effective methods for this purpose that are 
approved for commercial use in the US involve the controlled administration of heat to soybeans (i.e., expeller processing and roasting of soybeans) or heat plus reducing sugars to SSBM [i.e., heated, xylose-treated soybean meal (NSBM); Cleale et al., 1987; Firkins and Fluharty, 2000; Grummer and Rabelo, 2000). Estimations by the NRC (2001) for dairy cows consuming DM at $4 \%$ of BW in a $1: 1$ forage to concentrate ratio indicate that these methods can decrease ruminal degradability of proteins in raw soybeans by about $11 \%$ (roasting of whole seeds) and of proteins in soybean meal by about $62 \%$ (expeller processing) and 86\% (heated, xylose treatment) without negatively affecting (Harstad and Prestlokken, 2000), and sometimes even improving (Tice et al., 1993), their intestinal digestibility.

Numerous studies have examined the lactational response of dairy cows to the feeding of heat-treated soybean seeds or soybean meal. Surprisingly, much less attention has been given to the effects of these treatments on the intestinal supply of N and AA (Santos et al., 1998; Ipharraguerre and Clark, 2005). Indeed, only a few studies with dairy cows have been undertaken, and a summary of 9 comparisons from those experiments (Ipharraguerre and Clark, 2005) showed that replacing SSBM with soy protein supplements of reduced ruminal degradability increased $(25.2 \%)$ the passage to the duodenum of nonammonia nonmicrobial $\mathrm{N}$ (NANMN), but only improved marginally $(P>0.05)$ that of EAA (4.7\%), Lys (3.9\%), and Met (0.6\%). Additionally, to our knowledge, the impact of heat-treated soy protein supplements on the ruminal outflow of $\mathrm{N}$ and starch has not been compared in the same study with lactating dairy cows. Therefore, it is likely that the paucity of data from in vivo experiments limits the use of current protein systems for predicting accurately the supply of AA to dairy cows fed diets containing rumen-protected soy protein supplements.

The objectives of this study were to compare the effects of partially replacing SSBM with expeller soybean meal (ESBM), NSBM, or whole roasted soybeans (WRSB) in the diet of lactating dairy cows on ruminal fermentation, passage of nutrients to the small intestine, and nutrient digestibility.

\section{MATERIALS AND METHODS}

\section{Animals, Management, and Experimental Design}

Four multiparous Holstein cows that averaged 205 DIM (range, 152 to 268 DIM) at the onset of the experiment were surgically fitted with ruminal and duodenal cannulas according to procedures approved by the University of Illinois Laboratory Animal Care Advisory Committee. The ruminal cannulas were constructed of soft plastic (Bar Diamond, Parma, ID) and measured
$10.2 \mathrm{~cm}$ in diameter. The duodenal cannulas were an enclosed T-shaped design made of stainless steel (Berzins Vet Laboratory Ltd., Edmonton, Alberta, Canada). They were placed proximal to the common bile and pancreatic duct, about $10 \mathrm{~cm}$ distal to the pylorus. Cows were housed in individual stanchions equipped with water bowls and bedded with rubber mats and straw. With the exception of the last $3 \mathrm{~d}$ of each period when samples were being collected, cows were allowed to exercise in a dry lot from 0800 to $0900 \mathrm{~h}$. Cows were fed a TMR at 0600 and $1700 \mathrm{~h}$ for ad libitum intake and were milked twice daily at the same time.

The experimental design was a $4 \times 4$ Latin square with 14-d periods. The first $7 \mathrm{~d}$ of each period were used to adapt the cows to treatments, and the remaining 7 d were used to collect data. Each cow was randomly assigned to one of 4 treatment sequences in which a treatment never followed the same treatment for all sequences. The control diet contained $40.07 \%$ forage; $40.51 \%$ corn, minerals, and vitamins; and $19.42 \%$ SSBM (Table 1). For the other 3 dietary treatments, SSBM was replaced with ESBM, NSBM, or WRSB to supply $10.20 \%$ of the dietary DM. All diets were formulated to contain $18 \% \mathrm{CP}$ and to meet the NRC (2001) recommendations for all other nutrients. Diets were adjusted weekly to reflect changes in DM of forages and concentrate mixtures by drying each component overnight in an oven at $105^{\circ} \mathrm{C}$.

\section{Sampling, Measurements, and Analyses}

Dry matter intake and orts were measured and recorded daily. Samples of individual feed ingredients, TMR, and orts were collected for the last $5 \mathrm{~d}$ of each period. Samples of individual feedstuffs and TMR were dried at $55^{\circ} \mathrm{C}$ in an oven for $72 \mathrm{~h}$, ground through a 2$\mathrm{mm}$ screen in a Wiley Mill (Arthur H. Thomas, Philadelphia, PA), composited on an equal weight basis by period, and ground through a 1-mm screen. Samples of orts were dried at $55^{\circ} \mathrm{C}$ in an oven for $72 \mathrm{~h}$, ground through a $2-\mathrm{mm}$ screen, composited by the amount and dry weight of the daily orts for each cow, and ground through a 1-mm screen. Samples of feeds, TMR, and orts were analyzed for DM, OM, Kjeldahl N (AOAC, 1990), ADF (Van Soest et al., 1991), NDF with heatstable $\alpha$-amylase (Thermamyl 120L; Novo Nordisk Biochem, Franklinton, NC), sodium sulfite (Van Soest et al., 1991), and starch (Kartchner and Theurer, 1981). Except for Met, samples of feeds and TMR were prepared for AA determination, except Met, which was determined by acid hydrolysis with $6 \mathrm{~N} \mathrm{HCl}$ (McCarthy et al., 1989). For Met determination, samples were first oxidized with performic acid, lyophilized after dilution with water to remove excess performic acid (Overton 
Table 1. Ingredient composition of the experimental diets (DM basis).

\begin{tabular}{|c|c|c|c|c|}
\hline & \multicolumn{4}{|c|}{ Treatment $^{1}$} \\
\hline & SSBM & ESBM & NSBM & WRSB \\
\hline \multicolumn{5}{|l|}{ Ingredient } \\
\hline Alfalfa silage, $\%$ & 15.01 & 15.01 & 15.01 & 15.01 \\
\hline Corn silage, $\%$ & 25.06 & 25.06 & 25.06 & 25.06 \\
\hline Ground shelled corn, \% & 36.86 & 36.00 & 36.88 & 34.29 \\
\hline \multicolumn{5}{|l|}{ Soybean meal } \\
\hline Solvent-extracted (49\% CP), \% & 19.42 & 10.10 & 9.20 & 11.80 \\
\hline Expeller, ${ }^{2} \%$ & $\ldots$ & 10.20 & & $\ldots$ \\
\hline Heated, xylose-treated, ${ }^{3} \%$ & $\ldots$ & $\ldots$ & 10.20 & $\ldots$ \\
\hline Whole roasted soybeans, ${ }^{4} \%$ & $\ldots$ & $\ldots$ & $\ldots$ & 10.20 \\
\hline Sodium bicarbonate, $\%$ & 1.04 & 1.04 & 1.04 & 1.04 \\
\hline Dicalcium phosphate, $\%$ & 0.47 & 0.47 & 0.47 & 0.47 \\
\hline Limestone, \% & 1.30 & 1.30 & 1.30 & 1.30 \\
\hline Mineral and vitamin $\operatorname{mix},{ }^{5} \%$ & 0.26 & 0.26 & 0.26 & 0.26 \\
\hline Magnesium oxide, \% & 0.21 & 0.19 & 0.21 & 0.20 \\
\hline Sodium sulfate, \% & 0.37 & 0.37 & 0.37 & 0.37 \\
\hline \multicolumn{5}{|l|}{ Chemical } \\
\hline DM, \% & 66.5 & 66.8 & 66.7 & 66.8 \\
\hline $\mathrm{OM}, \%$ & 92.7 & 92.5 & 92.4 & 93.0 \\
\hline $\mathrm{CP}, \%$ & 18.2 & 18.1 & 18.2 & 18.3 \\
\hline RUP, ${ }^{6} \%$ & 6.8 & 8.2 & 8.8 & 6.6 \\
\hline RUP, ${ }^{6} \%$ of CP & 37.4 & 45.2 & 48.3 & 36.1 \\
\hline $\mathrm{RDP},{ }^{6} \%$ & 11.4 & 9.9 & 9.4 & 11.7 \\
\hline \multicolumn{5}{|l|}{ Metabolizable protein, ${ }^{6} \mathrm{~g} / \mathrm{d}$} \\
\hline Bacterial & 1104 & 1189 & 1081 & 1105 \\
\hline RUP & 1176 & 1570 & 1629 & 1097 \\
\hline Endogenous & 93 & 101 & 99 & 92 \\
\hline $\mathrm{NDF}, \%$ & 24.2 & 25.4 & 27.1 & 26.5 \\
\hline $\mathrm{ADF}, \%$ & 13.3 & 13.3 & 13.3 & 13.8 \\
\hline Starch, \% & 35.3 & 34.8 & 35.8 & 33.7 \\
\hline Ether extract, ${ }^{6} \%$ & 2.9 & 3.6 & 3.0 & 4.6 \\
\hline $\mathrm{NE}_{\mathrm{L}},{ }^{6} \mathrm{Mcal} / \mathrm{kg}$ of $\mathrm{DM}$ & 1.67 & 1.67 & 1.66 & 1.73 \\
\hline
\end{tabular}

${ }^{1} \mathrm{ESBM}=$ Expeller soybean meal; NSBM = heated, xylose-treated soybean meal; $\mathrm{SSBM}=$ solvent-extracted soybean meal; and WRSB = whole roasted soybeans.

${ }^{2}$ SoyPLUS (West Central Cooperative, Ralston, IA).

${ }^{3}$ Soy Pass (Ligno Tech USA, Inc., Rothschild, WI).

${ }^{4}$ Vita Plus Corp. (Madison, WI); protein dispersibility index $=8.96$.

${ }^{5}$ Contained $5.0 \% \mathrm{Mg}, 7.5 \% \mathrm{~K}, 10.0 \% \mathrm{~S}, 3.0 \% \mathrm{Zn}, 3.0 \% \mathrm{Mn}, 2.0 \% \mathrm{Fe}, 0.5 \% \mathrm{Cu}, 0.025 \% \mathrm{I}, 0.015 \% \mathrm{Se}, 0.004 \%$ Co, $2200 \mathrm{IU}$ of vitamin $\mathrm{A} / \mathrm{g}, 660 \mathrm{IU}$ of vitamin $\mathrm{D}_{3} / \mathrm{g}$, and $8 \mathrm{IU}$ of vitamin $\mathrm{E} / \mathrm{g}$.

${ }^{6}$ Calculated using NRC model (2001), the chemical composition of ingredients (Table 2), and least squares means for intakes for each treatment (Table 3).

et al., 1995), and hydrolyzed with $6 \mathrm{~N} \mathrm{HCl}$ as outlined by Moore (1963). Individual AA were then separated by ion exchange chromatography on a Beckman 126AA AA analyzer equipped with a Beckman 12-cm column (Beckman Instruments Inc., Palo Alto, CA).

Samples of ruminal fluid and duodenal digesta were collected every $3 \mathrm{~h}$ during the last $3 \mathrm{~d}$ of each period. The sampling time was adjusted ahead $1 \mathrm{~h}$ daily so that a sample was obtained for each 1-h interval of the day (24 total samples). Ruminal fluid samples were taken from multiple sites in the rumen, and $\mathrm{pH}$ of ruminal fluid was measured immediately by glass electrode. After measurement of $\mathrm{pH}$, a subsample of $50 \mathrm{~mL}$ was acidified to $\mathrm{pH}<2$ with $50 \% \mathrm{H}_{2} \mathrm{SO}_{4}$ ( $\mathrm{vol} / \mathrm{vol}$ ), centrifuged at $27,000 \times g$ for $10 \mathrm{~min}$ at $4^{\circ} \mathrm{C}$, and the supernatant was frozen at $-20^{\circ} \mathrm{C}$ for later analyses. Following removal of the cap of the duodenal cannula, accumulated digesta was discarded, and when the flow appeared normal, $500 \mathrm{~mL}$ of duodenal contents were collected. Samples were pooled by cow and stored frozen in 20-L buckets at $-20^{\circ} \mathrm{C}$ until analyses.

Ruminal fluid samples taken at $0,1,2,3,5,7,9$, and $10 \mathrm{~h}$ after the morning feeding and at $0,1,2,3,5,7$, 9,11 , and $12 \mathrm{~h}$ after the afternoon feeding (17 total samples) were thawed, centrifuged at $27,000 \times g$ for 20 min at $4^{\circ} \mathrm{C}$, and an aliquot of $4 \mathrm{~mL}$ was diluted with $25 \%$ metaphosphoric acid (4:1). These subsamples were assayed with a gas chromatograph (model 5890 Series II; Hewlett-Packard, Avondale, PA) equipped with a 1.8-m glass column packed with $10 \% \mathrm{SP} 1200 / 1 \% \mathrm{H}_{3} \mathrm{PO}_{4}$ on 80/100 chromosorb W AW (Supelco, 1975) to determine the concentration of VFA. Nitrogen was the carrier gas, and the temperature of the injection port and column was $175^{\circ} \mathrm{C}$ and $125^{\circ} \mathrm{C}$, respectively. Ruminal 
$\mathrm{NH}_{3} \mathrm{~N}$ was determined according to the procedures outlined by Chaney and Marbach (1962) as modified by Cotta and Russell (1982).

Duodenal samples were thawed and homogenized for 5 min using a propeller-type mixer set at high speed. During continuous stirring, a representative subsample $(1000 \mathrm{~mL})$ of digesta was collected by vacuum. Samples then were poured into shallow pans, lyophilized, ground through a 1-mm screen, and analyzed for DM, OM, Kjeldhal N, starch, and AA as described above. The concentration of $\mathrm{NH}_{3} \mathrm{~N}$ in duodenal digesta was determined by steam distillation with $\mathrm{MgO}$ (Bremner and Keeney, 1965), and purines, used as a bacterial marker, were measured by the method of Zinn and Owens (1986).

Ruminal bacteria were isolated from samples (1000 $\mathrm{mL}$ ) of whole ruminal contents obtained from the reticulum near the reticulo-omasal orifice at 6 separate postfeeding times $(0,2,4,6,8$, and $10 \mathrm{~h})$ during the last 3 $\mathrm{d}$ of each period. Ruminal contents were blended in a Waring blender (Waring Products Division, New Hartford, CT) for $1 \mathrm{~min}$ at low speed and strained through 6 layers of cheesecloth; the effluents were used to prepare a bacteria-rich sample by differential centrifugation (Overton et al., 1995). Bacterial samples were pooled by cow within period and frozen at $-20^{\circ} \mathrm{C}$. These samples were lyophilized and analyzed for DM, OM, Kjeldahl N, AA, and purines by the methods described above.

During the last $6 \mathrm{~d}$ of each period, fecal grab samples were collected twice daily at 12 -h intervals. The sampling time was adjusted ahead $2 \mathrm{~h}$ daily so that a sample was obtained for each 2-h interval of the day (12 total samples). Samples were composited on an equal wet weight basis, dried at $55^{\circ} \mathrm{C}$, ground through a $1-\mathrm{mm}$ screen, and assayed for DM, OM, Kjeldahl N, and starch as described above.

Chromic oxide was used as an indigestible marker to assess the passage of digesta to the duodenum and fecal excretion by the cows. Gelatin capsules that contained $10 \mathrm{~g}$ of $\mathrm{Cr}_{2} \mathrm{O}_{3}$ powder were administered via the ruminal cannula at 0800 and $2000 \mathrm{~h}$ during the last $10 \mathrm{~d}$ of each period. Concentration of $\mathrm{Cr}$ in duodenal and fecal samples was quantified by atomic absorption spectroscopy (air plus acetylene flame; Perkin-Elmer, Norwalk, CT) after preparation of samples by the procedure of Williams et al. (1962).

Passage of microbial $\mathrm{N}$ and $\mathrm{OM}$ to the duodenum was calculated from the passage of DM and from the proportion of $\mathrm{N}$ or $\mathrm{OM}$ of bacterial origin, respectively. These proportions were estimated by dividing the $\mathrm{N}$ to purine ratio or the OM to purine ratio of isolated bacteria by the $\mathrm{N}$ to purine ratio or the $\mathrm{OM}$ to purine ratio of duodenal digesta. Passage of NANMN to the duodenum was calculated by subtracting passage of microbial $\mathrm{N}$ from passage of total NAN. Apparent digestibility of OM in the rumen was corrected for the passage of microbial OM to the duodenum to establish the amount of OM truly digested in the rumen.

Milk weights were recorded at each milking during the last $7 \mathrm{~d}$ of each period. Milk samples were taken at each milking during the last $7 \mathrm{~d}$ of each period, preserved with 2-bromo-2-nitropropane-1,3-diol, and stored at $4^{\circ} \mathrm{C}$. Samples were sent to Dairy One Cooperative Inc. (Ithaca, NY) for analyses of fat, CP, true protein, TS, and urea $\mathrm{N}$ by infrared procedures (AOAC, 1990; Foss 4000; Foss North America, Eden Prairie, $\mathrm{MN})$.

\section{Statistical Analyses}

Data were analyzed as a $4 \times 4$ Latin square using PROC MIXED of SAS (2000), with cow treated as a random variable and according to the following model:

$$
\mathrm{Y}_{\mathrm{ijk}}=\mu+\mathrm{C}_{\mathrm{i}}+\mathrm{P}_{\mathrm{j}}+\mathrm{T}_{\mathrm{k}}+\varepsilon_{\mathrm{ijk}}
$$

where

$$
\begin{aligned}
\mathrm{Y}_{\mathrm{ijk}} & =\text { dependent variable, } \\
\mu & =\text { overall mean, } \\
\mathrm{C}_{\mathrm{i}} & =\text { effect of cow } \mathrm{i}(\mathrm{i}=1,2,3,4), \\
\mathrm{P}_{\mathrm{j}} & =\text { effect of period } \mathrm{j}(\mathrm{j}=1,2,3,4), \\
\mathrm{T}_{\mathrm{k}} & =\text { effect of the treatment } \mathrm{k}(\mathrm{k}=1,2,3,4), \text { and } \\
\varepsilon_{\mathrm{ijk}} & =\text { residual error. }
\end{aligned}
$$

A multiple comparison test (protected Fisher's least square difference) was used to separate least squares means into significant main effects.

Ruminal VFA, $\mathrm{NH}_{3} \mathrm{~N}$, and $\mathrm{pH}$ data were analyzed as repeated measures in time using PROC MIXED of SAS (Littell et al., 1996) and according to the following model:

$$
\mathrm{Y}_{\mathrm{ijkl}}=\mu+\mathrm{C}_{\mathrm{i}}+\mathrm{P}_{\mathrm{j}}+\mathrm{T}_{\mathrm{k}}+\varepsilon_{\mathrm{ijk}}+\mathrm{H}_{\mathrm{l}}+\mathrm{TH}_{\mathrm{kl}}+\omega_{\mathrm{ijk} \mathrm{l}}
$$

where

$$
\begin{aligned}
\mathrm{Y}_{\mathrm{ijkl}} & =\text { dependent variable, } \\
\mu & =\text { overall mean } \\
\mathrm{C}_{\mathrm{i}} & =\text { effect of cow } \mathrm{i}(\mathrm{i}=1,2,3,4), \\
\mathrm{P}_{\mathrm{j}} & =\text { effect of period } \mathrm{j}(\mathrm{j}=1,2,3,4), \\
\mathrm{T}_{\mathrm{k}} & =\text { effect of the treatment } \mathrm{k}(\mathrm{k}=1,2,3,4), \\
\varepsilon_{\mathrm{ijk}} & =\text { whole plot error, } \\
\mathrm{H}_{\mathrm{l}}= & \text { effect of the sampling time } \mathrm{l}(\mathrm{l}=1,2, \ldots, 17), \\
\mathrm{TH}_{\mathrm{kl}}= & \text { interaction between treatment } \mathrm{k} \text { and sampling } \\
& \text { time } \mathrm{l}, \text { and } \\
\omega_{\mathrm{ijkl}}= & \text { split plot error. }
\end{aligned}
$$


Table 2. Chemical composition of forages and protein supplements.

\begin{tabular}{|c|c|c|c|c|c|c|}
\hline \multirow[b]{2}{*}{ Item } & \multicolumn{2}{|c|}{ Silages } & \multicolumn{4}{|c|}{ Protein supplement $^{1}$} \\
\hline & Alfalfa & Corn & SSBM & ESBM & NSBM & $\mathrm{WRSB}^{2}$ \\
\hline $\mathrm{OM}, \%$ & 89.4 & 95.7 & 93.9 & 92.6 & 93.1 & 94.7 \\
\hline NDF, \% & 46.0 & 39.5 & 7.0 & 16.7 & 30.4 & 21.4 \\
\hline $\mathrm{ADF}, \%$ & 35.5 & 23.4 & 6.0 & 8.0 & 7.1 & 11.4 \\
\hline Starch, \% & 1.1 & 28.9 & 1.3 & 0.9 & 4.3 & 3.8 \\
\hline $\mathrm{CP}, \%$ & 19.0 & 7.6 & 53.2 & 48.8 & 51.0 & 41.6 \\
\hline \multicolumn{7}{|l|}{$\mathrm{EAA},{ }^{3} \%$ of $\mathrm{CP}$} \\
\hline Arg & 3.03 & 2.38 & 7.67 & 6.67 & 6.80 & 7.49 \\
\hline His & 1.66 & 1.85 & 2.78 & 2.54 & 2.61 & 2.79 \\
\hline Ile & 4.88 & 3.73 & 5.30 & 4.89 & 5.11 & 5.36 \\
\hline Leu & 7.66 & 9.50 & 8.39 & 7.74 & 8.13 & 8.36 \\
\hline Lys & 4.87 & 2.64 & 6.83 & 5.88 & 5.62 & 6.63 \\
\hline Met & 1.37 & 2.24 & 1.26 & 1.37 & 1.31 & 1.18 \\
\hline Phe & 4.91 & 4.01 & 5.43 & 4.97 & 5.17 & 5.45 \\
\hline Thr & 3.90 & 2.93 & 3.87 & 3.23 & 3.55 & 3.72 \\
\hline Val & 6.24 & 4.95 & 5.70 & 5.24 & 5.51 & 5.64 \\
\hline Lys, \% of total EAA & 12.66 & 7.72 & 14.45 & 13.81 & 12.84 & 14.22 \\
\hline Met, \% of total EAA & 3.56 & 6.54 & 2.67 & 3.22 & 3.00 & 2.52 \\
\hline
\end{tabular}

${ }^{1} \mathrm{ESBM}=$ Expeller soybean meal; NSBM = heated, xylose-treated soybean meal; SSBM = solvent-extracted soybean meal; and WRSB = whole roasted soybeans.

${ }^{2}$ Protein dispersibility index $=8.96$.

${ }^{3} \mathrm{EAA}=$ Essential amino acids.

The smallest value for the Akaike's information criterion was used to select the most appropriate covariance structure (Littell et al., 1996). Because the treatment $\times$ hour interaction was not significant $(P>0.05)$ for the ruminal parameters measured, treatment effects were compared across treatment sampling times using the procedure described above.

Differences among treatments were considered to be significant when $P<0.05$, whereas when $P>0.05$ but $<0.10$ differences were considered to indicate a trend toward a significant effect.

\section{RESULTS AND DISCUSSION}

\section{Chemical Composition of Diets and Feed Ingredients}

The percentage of dietary CP averaged 18.2 for all diets (Table 1). The retrospective evaluation of the diets using the NRC (2001) model as outlined in Table 1 indicated that replacing SSBM with ESBM or NSBM, but not with WRSB, increased the percentage of dietary DM and CP supplied as RUP. As expected, variation in the percentage of $\mathrm{NDF}(\mathrm{SD}=1.30), \mathrm{ADF}(\mathrm{SD}=0.40)$, and starch $(\mathrm{SD}=1.25)$ among diets was small.

The chemical composition of the protein supplements and forages (Table 2) was within the range reported in the literature (Miller and Hoover, 1998; NRC, 2001). With the exception of Met, ESBM and NSBM contained less EAA per unit of CP than SSBM and WRSB, which suggests that a larger proportion of EAA, especially Lys, might have been irreversibly bound to carbohy- drates in ESBM and NSBM than in SSBM and WRSB, impeding their release during the acid hydrolysis performed prior to analysis (Firkins and Fluharty, 2000). Alternatively, differences in the AA composition among sources of soybeans used to manufacture the soy products evaluated in this experiment might have contributed to these findings. Other researchers have reported similar variability for the concentration of EAA between SSBM and ESBM (Maiga et al., 1996) or NSBM (Harstad and Prestlokken, 2000).

\section{Intakes and Digestibilities of DM, OM, and Starch}

The intakes of DM and OM were not significantly affected by treatments and averaged 20.4 and $18.8 \mathrm{~kg} / \mathrm{d}$, respectively (Table 3 ). Other researchers also reported that replacing SSBM with ESBM (Reynal and Broderick, 2003), NSBM (Mansfield and Stern, 1994), or WRSB (Knapp et al., 1991) to provide varying proportions of the dietary DM did not affect DMI of lactating cows. In some experiments, however, feeding WRSB depressed DMI when compared with SSBM (Mohamed et al., 1988; Pires et al., 1996).

The amount and proportion of DM apparently digested in the total tract were unaffected by the soy protein supplements. Similarly, the amount and proportion of OM digested in the rumen (apparent and true digestion) and total tract as well as the amount of OM that passed to and was digested in the intestines was not different among treatments. Previous work also showed a lack of changes in these parameters in re- 
Table 3. Least square means for intakes and digestibilities of $\mathrm{DM}$ and $\mathrm{OM}$ in various segments of the gastrointestinal tract of lactating dairy cows fed diets containing different rumen-protected soy products.

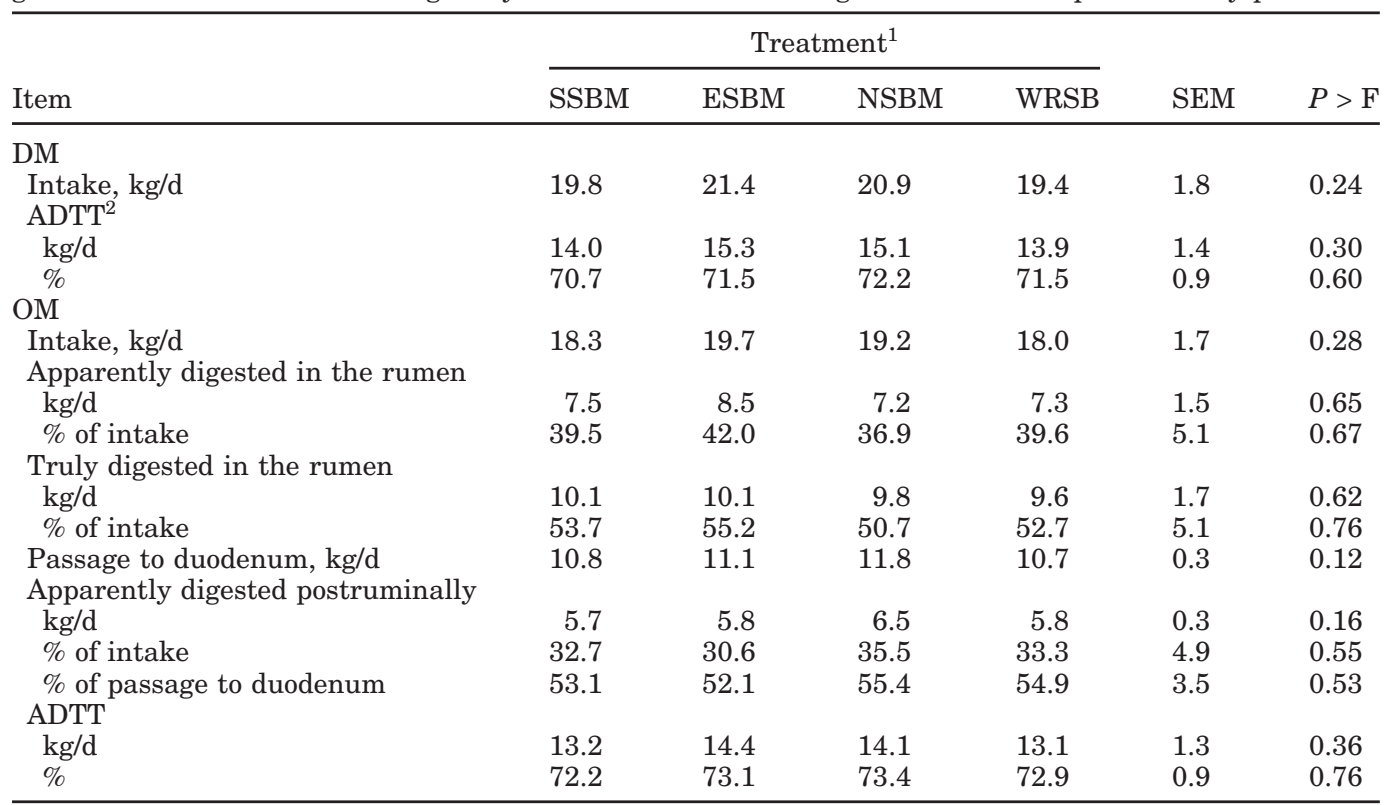

${ }^{1} \mathrm{ESBM}=$ Expeller soybean meal; NSBM = heated, xylose-treated soybean meal; $\mathrm{SSBM}=$ solvent-extracted soybean meal; and WRSB = whole roasted soybeans.

${ }^{2} \mathrm{ADTT}=$ Apparently digested in the total gastrointestinal tract.

sponse to the supplementation of diets for dairy cows (Mansfield and Stern, 1994; Reynal and Broderick, 2003) or steers (Cleale et al., 1987; Ludden et al., 1995) with the same treated soy supplements.

Intake, apparent ruminal and total tract digestibility (amount and percentage), flow to duodenum, and the apparent postruminal digestibility (amounts and proportions) of starch were not significantly influenced by treatments (Table 4). In relation to numerical trends, feeding WRSB tended to decrease the quantity of starch that was apparently digested in the total digestive tract compared with ESBM and NSBM. Because the percentage of starch that was digested in the total tract did not follow the same trend, this response can be attributed to the numerically smaller amount of starch consumed by cows fed WRSB, which probably arose from small variations in both DMI and starch content of the diet (smaller proportion of corn grain in the WRSB diet).

Table 4. Least square means for intake and digestibility of starch in various segments of the gastrointestinal tract of lactating dairy cows fed diets containing different rumen-protected soy products.

\begin{tabular}{|c|c|c|c|c|c|c|}
\hline \multirow[b]{2}{*}{ Item } & \multicolumn{4}{|c|}{ Treatment $^{1}$} & \multirow[b]{2}{*}{ SEM } & \multirow[b]{2}{*}{$P>\mathrm{F}$} \\
\hline & SSBM & ESBM & NSBM & WRSB & & \\
\hline \multicolumn{7}{|l|}{ Starch } \\
\hline Intake, $\mathrm{kg} / \mathrm{d}$ & 7.0 & 7.7 & 7.4 & 6.4 & 0.7 & 0.11 \\
\hline \multicolumn{7}{|c|}{ Apparently digested in the rumen } \\
\hline $\mathrm{kg} / \mathrm{d}$ & 4.0 & 4.7 & 4.2 & 4.0 & 0.7 & 0.37 \\
\hline$\%$ of intake & 55.6 & 59.7 & 57.2 & 61.3 & 5.7 & 0.59 \\
\hline Passage to duodenum, kg/d & 3.0 & 2.8 & 3.0 & 2.4 & 0.3 & 0.46 \\
\hline \multicolumn{7}{|c|}{ Apparently digested postruminally } \\
\hline $\mathrm{kg} / \mathrm{d}$ & 2.8 & 2.6 & 2.8 & 2.2 & 0.3 & 0.38 \\
\hline$\%$ of intake & 41.2 & 37.0 & 39.5 & 36.0 & 5.9 & 0.59 \\
\hline$\%$ of passage to duodenum & 91.9 & 91.6 & 92.4 & 92.0 & 2.5 & 0.97 \\
\hline \multicolumn{7}{|l|}{$\mathrm{ADTT}^{2}$} \\
\hline $\mathrm{kg} / \mathrm{d}$ & 6.7 & 7.4 & 7.1 & 6.2 & 0.6 & 0.10 \\
\hline$\%$ & 96.7 & 96.5 & 96.3 & 97.3 & 0.8 & 0.43 \\
\hline
\end{tabular}

${ }^{1} \mathrm{ESBM}=$ Expeller soybean meal; NSBM = heated, xylose-treated soybean meal; SSBM = solvent-extracted soybean meal; and WRSB = whole roasted soybeans.

${ }^{2} \mathrm{ADTT}=$ Apparently digested in the total gastrointestinal tract. 
Table 5. Least square means for ruminal fermentation parameters of lactating dairy cows fed diets containing different rumen-protected soy products.

\begin{tabular}{|c|c|c|c|c|c|c|}
\hline \multirow[b]{2}{*}{ Item } & \multicolumn{4}{|c|}{ Treatment $^{1}$} & \multirow[b]{2}{*}{ SEM } & \multirow[b]{2}{*}{$P>\mathrm{F}$} \\
\hline & SSBM & ESBM & NSBM & WRSB & & \\
\hline $\mathrm{pH}$ & 5.82 & 5.86 & 5.83 & 5.74 & 0.05 & 0.12 \\
\hline Total VFA, $\mathrm{m} M$ & $123.9^{\mathrm{a}}$ & $115.4^{\mathrm{b}}$ & $125.5^{\mathrm{a}}$ & $123.2^{\mathrm{a}}$ & 4.07 & 0.02 \\
\hline Acetate, $\mathrm{mol} / 100 \mathrm{~mol}$ & $61.2^{\mathrm{b}}$ & $62.6^{\mathrm{a}}$ & $62.0^{\mathrm{a}}$ & $61.2^{\mathrm{b}}$ & 0.82 & 0.007 \\
\hline Propionate, $\mathrm{mol} / 100 \mathrm{~mol}$ & $23.9^{\mathrm{a}}$ & $22.3^{\mathrm{b}}$ & $22.2^{\mathrm{b}}$ & $24.1^{\mathrm{a}}$ & 0.58 & 0.001 \\
\hline Isobutyrate, $\mathrm{mol} / 100 \mathrm{~mol}$ & $1.1^{\mathrm{a}}$ & $0.9^{\mathrm{b}}$ & $0.9^{\mathrm{b}}$ & $1.0^{\mathrm{b}}$ & 0.06 & 0.003 \\
\hline Butyrate, mol/100 mol & $10.2^{\mathrm{c}}$ & $10.9^{b}$ & $10.6^{\mathrm{a}}$ & $10.7^{\mathrm{b}}$ & 0.28 & 0.001 \\
\hline Isovalerate, $\mathrm{mol} / 100 \mathrm{~mol}$ & $1.8^{\mathrm{a}}$ & $1.8^{\mathrm{a}}$ & $1.6^{\mathrm{b}}$ & $1.5^{\mathrm{c}}$ & 0.09 & 0.001 \\
\hline Valerate, $\mathrm{mol} / 100 \mathrm{~mol}$ & $1.8^{\mathrm{a}}$ & $1.6^{\mathrm{b}}$ & $1.5^{\mathrm{b}}$ & $1.6^{\mathrm{b}}$ & 0.11 & 0.001 \\
\hline $\mathrm{NH}_{3} \mathrm{~N}, \mathrm{mg} / \mathrm{dL}$ & $24.5^{\mathrm{a}}$ & $20.4^{\mathrm{b}}$ & $21.2^{\mathrm{b}}$ & $23.5^{\mathrm{a}}$ & 1.39 & 0.001 \\
\hline
\end{tabular}

To our knowledge, few studies with dairy cows have examined the impact that soy protein supplements have on the extent and site of starch digestion. Mansfield and Stern (1994) reported that the use of SSBM or lignosulfonate-treated SSBM (approximately $16.5 \%$ of the dietary DM) as the sole source of supplemental $\mathrm{CP}$ resulted in similar intake and digestibility (rumen and total tract) of nonstructural carbohydrates. Similarly, in another experiment, the complete replacement of SSBM with lignosulfonate- or xylose-treated SSBM ( $17 \%$ of the dietary DM) did not influence the ruminal fermentation of NSC or fiber fractions (Windschitl and Stern, 1988). Based on these data, it seems reasonable to speculate that alterations in the extent and site of starch digestion should not be expected when ESBM, NSBM, or WRSB are used to increase the RUP content of SSBM-based diets fed to dairy cows, unless they are overheated.

\section{Ruminal Fermentation}

The source of soy protein did not affect the mean ruminal $\mathrm{pH}$, which averaged 5.81 for all treatments (Table 5). Similar results were obtained in other studies with dairy cows (Knapp et al., 1991; Reynal and Broderick, 2003) or steers (Ludden and Cecava, 1995; Orias et al., 2002) in which heat-treated soy products were compared with SSBM or raw soybeans.

The concentration of VFA in ruminal fluid decreased when ESBM, but not NSBM or WRSB, replaced SSBM in the diet (Table 5). The molar proportion of acetate was higher for ESBM and NSBM than for SSBM and WRSB, whereas the opposite was observed for the molar percentage of propionate. The percentage of butyrate was highest for ESBM and WRSB, intermediate for NSBM, and lowest for SSBM. Although not always significant, similar changes in the molar proportion of ace- tate and (or) propionate have been reported in a number of studies in which SSBM was compared with ESBM (Ludden and Cecava, 1995; Reynal and Broderick, 2003) or NSBM (Windschitl and Stern, 1988). Similarly, results reported here agree with data from other experiments, indicating that the replacement of SSBM with roasted (Mohamed et al., 1988; Knapp et al., 1991) or extruded (Stern et al., 1985) soybeans has generally failed to alter the relative concentration of these VFA in ruminal fluid. Windschitl and Stern (1988) explained these changes in the molar proportions of acetate and propionate by suggesting that increasing the availability of true protein in the rumen by feeding more degradable protein sources stimulates the production of propionate more than acetate. Because the intake and ruminal fermentation of OM and starch were similar among treatments, this response might also be explained by a more rapid rate of degradation of $\mathrm{OM}$ and protein in SSBM than in ESBM and NSBM as well as by the lower fat content in the SSBM diet compared with the WRSB diet. To some extent, these observations are supported by data from experiments showing that the in situ rate of protein degradation of SSBM was significantly faster than that of ESBM (Maiga et al., 1996) or NSBM (Harstad and Prestlokken, 2000) and by the well-documented effects of lipids on the molar proportion of acetate and propionate (Jenkins, 1993).

The molar concentrations of isobutyrate and valerate were highest for SSBM and did not differ among the rumen-protected soy supplements. The percentage of isovalerate was highest for SSBM and ESBM, intermediate for NSBM, and lowest for WRSB. Because these VFA are the end products of the oxidative deamination and decarboxylation of branched-chain AA (Allison, 1978), it is likely that less feed protein was degraded in the rumen when SSBM was replaced with the other soy protein supplements in the diet. Some support for 
Table 6. Least square means for intake and digestibility of $\mathrm{N}$ in various segments of the gastrointestinal tract of lactating dairy cows fed diets containing different rumen-protected soy products.

\begin{tabular}{|c|c|c|c|c|c|c|}
\hline \multirow[b]{2}{*}{ Item } & \multicolumn{4}{|c|}{ Treatment $^{1}$} & \multirow[b]{2}{*}{ SEM } & \multirow[b]{2}{*}{$P>\mathrm{F}$} \\
\hline & SSBM & ESBM & NSBM & WRSB & & \\
\hline $\mathrm{N}$ intake, $\mathrm{g} / \mathrm{d}$ & 579 & 622 & 613 & 567 & 51.0 & 0.22 \\
\hline \multicolumn{7}{|l|}{ Passage to duodenum } \\
\hline \multicolumn{7}{|l|}{ Total N } \\
\hline $\mathrm{g} / \mathrm{d}$ & 502 & 543 & 590 & 529 & 31.4 & 0.08 \\
\hline$\%$ of $\mathrm{N}$ intake & 87.9 & 90.1 & 100.4 & 93.7 & 6.1 & 0.38 \\
\hline \multicolumn{7}{|l|}{ NAN } \\
\hline $\mathrm{g} / \mathrm{d}$ & $467^{\mathrm{b}}$ & $514^{\mathrm{ab}}$ & $564^{\mathrm{a}}$ & $498^{\mathrm{b}}$ & 5.1 & 0.05 \\
\hline$\%$ of $\mathrm{N}$ intake & 81.6 & 85.2 & 95.8 & 88.1 & 5.5 & 0.28 \\
\hline \multicolumn{7}{|l|}{ NANMN $^{2}$} \\
\hline $\mathrm{g} / \mathrm{d}$ & $222^{\mathrm{b}}$ & $283^{\mathrm{ab}}$ & $323^{\mathrm{a}}$ & $289^{\mathrm{a}}$ & 21.6 & 0.05 \\
\hline$\%$ of NAN & 48.4 & 56.0 & 58.5 & 57.9 & 3.5 & 0.15 \\
\hline$\%$ of $\mathrm{N}$ intake & 40.0 & 47.4 & 56.0 & 51.0 & 5.1 & 0.16 \\
\hline \multicolumn{7}{|l|}{ Microbial N } \\
\hline $\mathrm{g} / \mathrm{d}$ & 245 & 227 & 236 & 209 & 25.1 & 0.42 \\
\hline$\%$ of NAN & 51.6 & 43.9 & 41.5 & 42.1 & 3.5 & 0.15 \\
\hline $\mathrm{g} / \mathrm{kg}$ of $\mathrm{OMAD}^{3}$ & 35.4 & 30.7 & 35.6 & 30.3 & 5.5 & 0.49 \\
\hline $\mathrm{g} / \mathrm{kg}_{\mathrm{of}} \mathrm{OMTD}^{4}$ & 25.4 & 22.2 & 25.2 & 22.4 & 2.9 & 0.42 \\
\hline $\mathrm{g} / \mathrm{kg}$ of OMADTT ${ }^{5}$ & 18.2 & 16.4 & 17.3 & 16.1 & 1.3 & 0.50 \\
\hline \multicolumn{7}{|l|}{$\mathrm{N}$ digested postruminally } \\
\hline $\mathrm{g} / \mathrm{d}$ & 344 & 372 & 409 & 354 & 25.7 & 0.23 \\
\hline$\%$ of $\mathrm{N}$ intake & 60.2 & 62.4 & 70.8 & 62.6 & 6.0 & 0.50 \\
\hline$\%$ of $\mathrm{N}$ passage to duodenum & 68.5 & 69.1 & 70.6 & 66.9 & 2.4 & 0.68 \\
\hline \multicolumn{7}{|l|}{$\mathrm{N} \mathrm{ADTT}^{6}$} \\
\hline $\mathrm{g} / \mathrm{d}$ & 421 & 450 & 440 & 393 & 43.1 & 0.33 \\
\hline$\%$ & 72.3 & 72.8 & 71.9 & 69.0 & 1.7 & 0.32 \\
\hline \multicolumn{7}{|c|}{$\begin{array}{l}\text { a,b Values within the same row with uncommon superscripts are different }(P<0.05) \text {. Pairwise comparisons } \\
\text { were calculated using the appropriate standard error. }\end{array}$} \\
\hline \multicolumn{7}{|c|}{$\begin{array}{l}{ }^{1} \mathrm{ESBM}=\mathrm{Expeller} \mathrm{soybean} \text { meal; } \mathrm{NSBM}=\text { heated, xylose-treated soybean meal; } \mathrm{SSBM}=\text { solvent-extracted } \\
\text { soybean meal; and WRSB = whole roasted soybeans. }\end{array}$} \\
\hline \multicolumn{7}{|c|}{${ }^{2}$ NANMN = Nonammonia nonmicrobial N. } \\
\hline \multicolumn{7}{|c|}{${ }^{3} \mathrm{OMAD}=\mathrm{OM}$ Apparently digested in the rumen. } \\
\hline \multicolumn{7}{|c|}{${ }^{4}$ OMTD $=$ OM Truly digested in the rumen. } \\
\hline${ }^{5}$ OMADTT = OM Apparently & sted in & tal gast & stinal & & & \\
\hline
\end{tabular}

this hypothesis is provided by the finding that the $\mathrm{NH}_{3} \mathrm{~N}$ concentration in the rumen was highest for SSBM and WRSB and lowest for ESBM and NSBM. Previous work also showed that the replacement of SSBM with NSBM (from 13.8 to $17 \%$ of the dietary DM) decreased the molar proportion of branched-chain VFA and the concentration of $\mathrm{NH}_{3} \mathrm{~N}$ in ruminal fluid (Windschitl and Stern, 1988; Mansfield and Stern, 1994). Also, in agreement with our results, the substitution of WRSB for SSBM to supply 12 to $24 \%$ of the dietary DM decreased the percentage of isobutyrate (Mohamed et al., 1988) or valerate (Knapp et al., 1991) without altering the ruminal $\mathrm{NH}_{3} \mathrm{~N}$ concentration (Mohamed et al., 1988). However, changes in the concentration of isoacids and (or) $\mathrm{NH}_{3} \mathrm{~N}$ in response to the replacement of SSBM or raw soybeans with heat-treated soy supplements have not always been observed (Ludden and Cecava, 1995; Reynal and Broderick, 2003).

\section{Intake and Ruminal Outflow of Nitrogen}

The intake of $\mathrm{N}$ ranged from 567 to $622 \mathrm{~g} / \mathrm{d}$, but differences among treatments were not significant (Table 6). The amount of total $\mathrm{N}$ that passed to the duodenum tended to be greater for NSBM than for SSBM and WRSB. This trend, however, was not evident when passage of $\mathrm{N}$ was expressed as a percentage of $\mathrm{N}$ intake. Compared with SSBM, the ruminal outflow of NAN was higher for NSBM $(+20.8 \%)$, tended $(P<0.09)$ to be higher for ESBM $(+10.1 \%)$, and was similar for WRSB. These increases in ruminal outflow of NAN were the results of the intestinal supply of NANMN being higher for $\operatorname{NSBM}(+44.5 \%)$ and WRSB $(+30.2 \%)$ and tending $(P$ $<0.08)$ to be higher for ESBM $(+27.5 \%)$. Among rumenprotected soy products, ruminal escape of NAN was higher for NSBM than for WRSB. Conversely, the source of soy protein did not affect the passage of microbial $\mathrm{N}$ to the small intestine (expressed as g/d or per- 
Table 7. Least square means for intakes of AA by lactating dairy cows fed diets containing different rumenprotected soy products.

\begin{tabular}{|c|c|c|c|c|c|c|}
\hline \multirow[b]{2}{*}{ Item } & \multicolumn{4}{|c|}{ Treatment $^{1}$} & \multirow[b]{2}{*}{ SEM } & \multirow[b]{2}{*}{$P>\mathrm{F}$} \\
\hline & SSBM & ESBM & NSBM & WRSB & & \\
\hline \multicolumn{7}{|l|}{ Essential } \\
\hline Arg & $212^{\mathrm{b}}$ & $256^{\mathrm{a}}$ & $223^{\mathrm{b}}$ & $262^{\mathrm{a}}$ & 21.9 & 0.02 \\
\hline His & $94^{\mathrm{b}}$ & $115^{\mathrm{a}}$ & $100^{\mathrm{b}}$ & $88^{\mathrm{b}}$ & 9.3 & 0.02 \\
\hline Ile & $167^{\mathrm{c}}$ & $209^{a}$ & $190^{\mathrm{ab}}$ & $168^{\mathrm{bc}}$ & 17.1 & 0.03 \\
\hline Leu & $340^{\mathrm{bc}}$ & $390^{\mathrm{a}}$ & $359^{\mathrm{ab}}$ & $313^{\mathrm{c}}$ & 32.4 & 0.04 \\
\hline Lys & $206^{\mathrm{b}}$ & $241^{\mathrm{a}}$ & $206^{\mathrm{b}}$ & $189^{b}$ & 19.7 & 0.04 \\
\hline Met & 60 & 66 & 64 & 57 & 5.5 & 0.11 \\
\hline Phe & $192^{\mathrm{bc}}$ & $225^{\mathrm{a}}$ & $205^{\mathrm{ab}}$ & $180^{\mathrm{c}}$ & 18.6 & 0.04 \\
\hline Thr & $153^{\mathrm{a}}$ & $161^{\mathrm{a}}$ & $144^{\mathrm{a}}$ & $126^{\mathrm{b}}$ & 13.6 & 0.03 \\
\hline Val & $189^{\mathrm{b}}$ & $243^{\mathrm{a}}$ & $222^{\mathrm{a}}$ & $194^{\mathrm{b}}$ & 19.8 & 0.02 \\
\hline Total & 1613 & 1908 & 1711 & 1577 & 159.1 & 0.07 \\
\hline \multicolumn{7}{|c|}{ Nonessential } \\
\hline Ala & $217^{\mathrm{ab}}$ & $246^{\mathrm{a}}$ & $226^{\mathrm{a}}$ & $196^{\mathrm{b}}$ & 20.6 & 0.04 \\
\hline Asp & $417^{\mathrm{bc}}$ & $481^{\mathrm{a}}$ & $432^{\mathrm{ab}}$ & $379^{\mathrm{c}}$ & 39.6 & 0.04 \\
\hline Glu & $663^{\mathrm{bc}}$ & $774^{\mathrm{a}}$ & $699^{\mathrm{ab}}$ & $604^{\mathrm{c}}$ & 63.4 & 0.03 \\
\hline Gly & $172^{\mathrm{bc}}$ & $200^{\mathrm{a}}$ & $180^{\mathrm{ab}}$ & $157^{\mathrm{c}}$ & 16.5 & 0.04 \\
\hline Pro & $252^{\mathrm{ab}}$ & $286^{\mathrm{a}}$ & $264^{\mathrm{a}}$ & $231^{\mathrm{b}}$ & 23.7 & 0.05 \\
\hline Ser & $190^{\mathrm{a}}$ & $171^{\mathrm{ab}}$ & $149^{b}$ & $128^{\mathrm{c}}$ & 15.1 & 0.003 \\
\hline Tyr & $92^{\mathrm{bc}}$ & $114^{\mathrm{a}}$ & $102^{\mathrm{ab}}$ & $87^{\mathrm{c}}$ & 9.2 & 0.02 \\
\hline Total & $2004^{\mathrm{ab}}$ & $2270^{\mathrm{a}}$ & $2052^{\mathrm{a}}$ & $1782^{\mathrm{b}}$ & 187.9 & 0.04 \\
\hline Total AA & $3617^{\mathrm{b}}$ & $4178^{\mathrm{a}}$ & $3764^{\mathrm{ab}}$ & $3359^{b}$ & 345.2 & 0.05 \\
\hline
\end{tabular}

${ }^{\mathrm{a}, \mathrm{b}, \mathrm{c}}$ Values within the same row with uncommon superscripts are different $(P<0.05)$. Pairwise comparisons were calculated using the appropriate standard error.

${ }^{1} \mathrm{ESBM}=$ Expeller soybean meal; NSBM = heated, xylose-treated soybean meal; $\mathrm{SSBM}=$ solvent-extracted soybean meal; and WRSB = whole roasted soybeans.

centage of NAN flow) or the efficiency of microbial growth.

These results agree with those from a meta-analysis of 9 treatment comparisons (Ipharraguerre and Clark, 2005), showing that the replacement of SSBM with rumen-protected soy products in the diet of lactating cows did not influence the intestinal supply of microbial $\mathrm{N}$ but increased the outflow from the rumen of NAN (range $=3.7$ to $17.5 \%)$ and NANMN (range $=10$ to $42.5 \%$ ). In this experiment, no differences were detected among SSBM and the rumen-protected soy supplements when the flow to duodenum of NAN and NANMN were expressed as percentage of $\mathrm{N}$ intake (or percentage of NAN flow), suggesting that variation in the intake of DM and $\mathrm{N}$ might have accounted for the increased intestinal supply of NAN and NANMN elicited by NSBM and ESBM. Similarly, Mansfield and Stern (1994) and Reynal and Broderick (2003) did not detect improvements in the proportional contribution of NANMN to the ruminal outflow of NAN in dairy cows fed NSBM or ESBM, respectively.

Apparent $\mathrm{N}$ digestion in the intestines and total tract was unaltered by treatments (Table 6). Similar to results from this experiment, other researchers have reported no change in intestinal and (or) total tract digestibility of N when heated SSBM (Mabjeesh et al., 1996), NSBM (Cleale et al., 1987; Mansfield and Stern, 1994), or ESBM (Ludden and Cecava, 1995) were compared with SSBM.

\section{Intake and Ruminal Outflow of AA}

With the exception of Met, Thr, Ala, Pro, Ser, and total nonessential AA (NEAA), replacing SSBM with ESBM increased the intake of individual EAA and NEAA, total EAA $(P<0.07)$, and total AA (Table 7). These differences were less pronounced when NSBM or WRSB were compared with SSBM. That is, NSBM increased the intake of Ile and Val and decreased the intake of Ser; WRSB enhanced the intake of Arg but depressed that of Thr and Ser. Among rumen-protected soy supplements, the intakes of His, Lys, and total EAA $(P<0.07)$ were largest for ESBM and those of Leu, Phe, Thr, Val, and NEAA (i.e., individual and total) were lowest for WRSB. Because the source of supplemental $\mathrm{CP}$ was essentially the only ingredient that varied in the diets, these results can be attributed to variations in DMI (Table 3) and in the AA composition of the soy protein supplements (Table 2). In other trials, the replacement of SSBM with heated SSBM (Mabjeesh et al., 1996), NSBM (Windschitl and Stern, 1988), or extruded soybeans (Stern et al., 1985) also altered AA intake. 
Table 8. Least square means for passage of microbial AA to the duodenum of lactating dairy cows fed diets containing different rumen-protected soy products.

\begin{tabular}{|c|c|c|c|c|c|c|}
\hline \multirow[b]{2}{*}{ Item } & \multicolumn{4}{|c|}{ Treatment $^{1}$} & \multirow[b]{2}{*}{ SEM } & \multirow[b]{2}{*}{$P>\mathrm{F}$} \\
\hline & SSBM & ESBM & NSBM & WRSB & & \\
\hline & & & & & & \\
\hline \multicolumn{7}{|l|}{ Essential } \\
\hline Arg & 67 & 56 & 60 & 54 & 8.6 & 0.48 \\
\hline $\mathrm{His}$ & 27 & 22 & 24 & 22 & 3.6 & 0.55 \\
\hline Ile & 80 & 71 & 73 & 67 & 10.6 & 0.64 \\
\hline Leu & 110 & 94 & 99 & 89 & 13.9 & 0.53 \\
\hline Lys & 105 & 89 & 93 & 85 & 13.0 & 0.48 \\
\hline Met & 32 & 33 & 30 & 28 & 5.5 & 0.85 \\
\hline Phe & 69 & 60 & 63 & 57 & 9.0 & 0.59 \\
\hline Thr & 69 & 57 & 60 & 54 & 7.5 & 0.29 \\
\hline Val & 91 & 80 & 82 & 76 & 12.5 & 0.62 \\
\hline Total & 651 & 563 & 583 & 533 & 82.8 & 0.54 \\
\hline \multicolumn{7}{|c|}{ Nonessential } \\
\hline Ala & 105 & 89 & 92 & 85 & 13.1 & 0.50 \\
\hline Asp & 164 & 139 & 145 & 132 & 19.8 & 0.46 \\
\hline Glu & 174 & 149 & 154 & 140 & 21.4 & 0.49 \\
\hline Gly & 87 & 77 & 79 & 72 & 11.9 & 0.64 \\
\hline Pro & 51 & 43 & 44 & 40 & 6.4 & 0.48 \\
\hline Ser & 49 & 38 & 43 & 37 & 5.0 & 0.18 \\
\hline Tyr & 52 & 44 & 47 & 42 & 6.0 & 0.38 \\
\hline Total & 682 & 579 & 604 & 549 & 82.7 & 0.46 \\
\hline Total AA & 1333 & 1141 & 1188 & 1081 & 165.5 & 0.50 \\
\hline
\end{tabular}

${ }^{1} \mathrm{ESBM}=$ Expeller soybean meal; NSBM = heated, xylose-treated soybean meal; SSBM = solvent-extracted soybean meal; and WRSB = whole roasted soybeans.

The source of soy protein did not influence the ruminal outflow of individual AA, total EAA, total NEAA, and total AA of microbial origin (Table 8), but affected markedly the ruminal escape of AA in the NANMN (Table 9) and NAN fractions (Table 10). With the exception of Met, Ser, and Tyr, partially replacing SSBM with NSBM improved or tended to improve (i.e., Ile, Lys, Val, and Gly) the intestinal supply of all other EAA and NEAA (Table 10). Similar improvements in the amount of AA that reached the small intestines of lactating cows were observed when heated and unheated SSBM were compared (Mabjeesh et al., 1996). However, Windschitl and Stern (1988) reported that only the passage to the duodenum of Glu and Pro increased when SSBM was replaced with xylose- or lignosulfonate-treated SSBM in the diet of dairy cows. In another experiment (Mansfield and Stern, 1994), the amount of AA delivered to the lower digestive tract of dairy cows did not change when SSBM was totally replaced with lignosulfonate-treated SSBM. In comparison with SSBM, supplementing the diet with WRSB increased the passage to duodenum of Arg, His, Ile $(P$ $<0.06)$, Leu, Lys $(P<0.06)$, Phe, Val $(P<0.06)$, Asp, Glu, Gly $(P<0.07)$, Pro, total NEAA, and total AA (Table 10). Previous work showed that the postruminal supply of most EAA and NEAA was not enhanced when extruded soybeans were compared with SSBM (Stern et al., 1985). Apart from Glu and Pro, the partial re- placement of SSBM with ESBM did not alter the amount of AA that passed to the lower digestive tract (Table 10). Other researchers also found that diets supplemented with either SSBM or ESBM resulted in similar amounts of AA delivered to the small intestine of dairy cows (Reynal et al., 2003) and steers (Ludden and Cecava, 1995). Among the rumen-protected soy products, the ruminal outflow of Leu, Thr, Ala, Asp, Glu, Pro, and total AA was highest for NSBM (Table 10). In comparison with ESBM, feeding NSBM and WRSB tended to increase postruminal supplies of $\operatorname{Arg}(P<$ 0.05), Ile, Lys, Val, and Gly. None of these RUP sources enhanced the amount of Met that reached the small intestine when compared with each other or with SSBM.

In agreement with results reported here, a metaanalytic review of 6 treatment comparisons (Ipharraguerre and Clark, 2005) indicated that replacing SSBM with rumen-protected soy products in the diet of lactating dairy cows increased numerically $(P>0.05)$ the intestinal supply of Lys and Met by 3.9 and $0.6 \%$, respectively. Additionally, the magnitude of the numerical improvement in the ruminal outflow of Lys that was elicited by NSBM $(18.7 \%)$ and WRSB (12\%) in this trial was within or slightly outside of the mean response range ( -5.5 to $14.3 \%)$ reported in that review. Regression analyses conducted by Rulquin and Vérité (1993) and the NRC (2001) showed that most of the variation 
Table 9. Least square means for passage of nonammonia nonmicrobial AA to the duodenum of lactating dairy cows fed diets containing different rumen-protected soy products.

\begin{tabular}{|c|c|c|c|c|c|c|}
\hline \multirow[b]{2}{*}{ Item } & \multicolumn{4}{|c|}{ Treatment $^{1}$} & \multirow[b]{2}{*}{ SEM } & \multirow[b]{2}{*}{$P>\mathrm{F}$} \\
\hline & SSBM & ESBM & NSBM & WRSB & & \\
\hline & 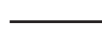 & 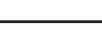 & 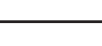 & - & & \\
\hline \multicolumn{7}{|l|}{ Essential } \\
\hline Arg & $54^{\mathrm{b}}$ & $67^{\mathrm{b}}$ & $95^{\mathrm{a}}$ & $87^{\mathrm{a}}$ & 6.2 & 0.004 \\
\hline $\mathrm{His}$ & $29^{\mathrm{c}}$ & $34^{\mathrm{bc}}$ & $45^{\mathrm{a}}$ & $40^{\mathrm{ab}}$ & 2.4 & 0.006 \\
\hline Ile & $58^{\mathrm{c}}$ & $63^{\mathrm{bc}}$ & $93^{\mathrm{a}}$ & $84^{\mathrm{ab}}$ & 7.9 & 0.03 \\
\hline Leu & 119 & 140 & 176 & 156 & 10.9 & 0.06 \\
\hline Lys & $61^{\mathrm{b}}$ & $75^{\mathrm{ab}}$ & $103^{\mathrm{a}}$ & $100^{\mathrm{a}}$ & 9.1 & 0.03 \\
\hline Met & 26 & 26 & 34 & 33 & 6.1 & 0.60 \\
\hline Phe & $58^{\mathrm{c}}$ & $69^{\mathrm{bc}}$ & $93^{\mathrm{a}}$ & $84^{\mathrm{ab}}$ & 5.7 & 0.02 \\
\hline Thr & $43^{b}$ & $60^{\mathrm{a}}$ & $71^{\mathrm{a}}$ & $66^{\mathrm{a}}$ & 4.8 & 0.02 \\
\hline Val & $64^{\mathrm{b}}$ & $70^{\mathrm{ab}}$ & $101^{\mathrm{a}}$ & $95^{\mathrm{a}}$ & 9.7 & 0.05 \\
\hline Total & $512^{\mathrm{c}}$ & $602^{\mathrm{bc}}$ & $812^{\mathrm{a}}$ & $746^{\mathrm{ab}}$ & 56.7 & 0.02 \\
\hline \multicolumn{7}{|c|}{ Nonessential } \\
\hline Ala & 66 & 80 & 103 & 97 & 9.6 & 0.06 \\
\hline Asp & $99^{c}$ & $129^{\mathrm{bc}}$ & $183^{\mathrm{a}}$ & $162^{\mathrm{ab}}$ & 13.7 & 0.008 \\
\hline Glu & $181^{\mathrm{c}}$ & $235^{\mathrm{bc}}$ & $311^{\mathrm{a}}$ & $259^{\mathrm{ab}}$ & 17.5 & 0.03 \\
\hline Gly & $61^{\mathrm{b}}$ & $68^{\mathrm{b}}$ & $95^{\mathrm{a}}$ & $94^{\mathrm{a}}$ & 8.2 & 0.02 \\
\hline Pro & $73^{\mathrm{b}}$ & $91^{\mathrm{ab}}$ & $112^{\mathrm{a}}$ & $94^{\mathrm{a}}$ & 6.0 & 0.03 \\
\hline Ser & 40 & 65 & 68 & 62 & 8.1 & 0.11 \\
\hline Tyr & $24^{\mathrm{b}}$ & $31^{\mathrm{b}}$ & $44^{\mathrm{a}}$ & $45^{\mathrm{a}}$ & 3.4 & 0.004 \\
\hline Total & $545^{\mathrm{c}}$ & $695^{\mathrm{bc}}$ & $914^{\mathrm{a}}$ & $812^{\mathrm{ab}}$ & 56.8 & 0.007 \\
\hline Total AA & $1057^{\mathrm{c}}$ & $1297^{\mathrm{bc}}$ & $1726^{\mathrm{ab}}$ & $1559^{\mathrm{ab}}$ & 111.3 & 0.009 \\
\hline
\end{tabular}

${ }^{\mathrm{a}, \mathrm{b}, \mathrm{c}}$ Values within the same row with uncommon superscripts are different $(P<0.05)$. Pairwise comparisons were calculated using the appropriate standard error.

${ }^{1} \mathrm{ESBM}=$ Expeller soybean meal; NSBM = heated, xylose-treated soybean meal; SSBM = solvent-extracted soybean meal; and WRSB = whole roasted soybeans.

Table 10. Least square means for passage of AA to the duodenum of lactating dairy cows fed diets containing different rumen-protected soy products.

\begin{tabular}{|c|c|c|c|c|c|c|}
\hline \multirow[b]{2}{*}{ Item } & \multicolumn{4}{|c|}{ Treatment $^{1}$} & \multirow[b]{2}{*}{ SEM } & \multirow[b]{2}{*}{$P>\mathrm{F}$} \\
\hline & SSBM & ESBM & NSBM & WRSB & & \\
\hline & & 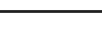 & & & & \\
\hline \multicolumn{7}{|l|}{ Essential } \\
\hline Arg & $121^{\mathrm{b}}$ & $124^{\mathrm{b}}$ & $155^{\mathrm{a}}$ & $141^{\mathrm{a}}$ & 7.5 & 0.04 \\
\hline His & $55^{\mathrm{c}}$ & $57^{\mathrm{bc}}$ & $69^{\mathrm{a}}$ & $61^{\mathrm{ab}}$ & 2.4 & 0.006 \\
\hline Ile & 139 & 135 & 167 & 151 & 7.9 & 0.06 \\
\hline Leu & $229^{c}$ & $240^{\mathrm{bc}}$ & $280^{\mathrm{a}}$ & $245^{b}$ & 10.9 & 0.003 \\
\hline Lys & 166 & 164 & 197 & 186 & 9.0 & 0.06 \\
\hline Met & 58 & 59 & 64 & 61 & 4.7 & 0.76 \\
\hline Phe & $127^{\mathrm{c}}$ & $132^{\mathrm{bc}}$ & $159^{\mathrm{a}}$ & $141^{\mathrm{ab}}$ & 5.8 & 0.01 \\
\hline Thr & $112^{\mathrm{b}}$ & $118^{\mathrm{b}}$ & $133^{\mathrm{a}}$ & $121^{\mathrm{b}}$ & 5.6 & 0.03 \\
\hline Val & 155 & 151 & 185 & 171 & 9.7 & 0.06 \\
\hline Total & $1163^{\mathrm{b}}$ & $1179^{\mathrm{b}}$ & $1409^{a}$ & $1279^{\mathrm{ab}}$ & 55.1 & 0.02 \\
\hline \multicolumn{7}{|c|}{ Nonessential } \\
\hline Ala & $171^{\mathrm{b}}$ & $173^{\mathrm{b}}$ & $200^{\mathrm{a}}$ & $182^{\mathrm{b}}$ & 8.5 & 0.03 \\
\hline Asp & $262^{\mathrm{c}}$ & $273^{\mathrm{bc}}$ & $334^{\mathrm{a}}$ & $294^{\mathrm{b}}$ & 13.5 & 0.009 \\
\hline Glu & $355^{\mathrm{c}}$ & $393^{b}$ & $475^{\mathrm{a}}$ & $399^{b}$ & 17.6 & 0.001 \\
\hline Gly & 148 & 144 & 174 & 166 & 8.5 & 0.07 \\
\hline Pro & $124^{\mathrm{c}}$ & $136^{\mathrm{b}}$ & $158^{\mathrm{a}}$ & $134^{\mathrm{b}}$ & 5.7 & 0.001 \\
\hline Ser & 90 & 104 & 112 & 99 & 8.0 & 0.17 \\
\hline Tyr & 77 & 75 & 91 & 87 & 7.0 & 0.11 \\
\hline Total & $1226^{\mathrm{c}}$ & $1299^{\mathrm{bc}}$ & $1544^{\mathrm{a}}$ & $1361^{\mathrm{ab}}$ & 59.0 & 0.004 \\
\hline Total AA & $2390^{c}$ & $2478^{\mathrm{bc}}$ & $2953^{\mathrm{a}}$ & $2640^{\mathrm{b}}$ & 112.4 & 0.01 \\
\hline
\end{tabular}

${ }^{\mathrm{a}, \mathrm{b}, \mathrm{c}}$ Values within the same row with uncommon superscripts are different $(P<0.05)$. Pairwise comparisons were calculated using the appropriate standard error.

${ }^{1} \mathrm{ESBM}=$ Expeller soybean meal; NSBM = heated, xylose-treated soybean meal; $\mathrm{SSBM}$ = solvent-extracted soybean meal; and WRSB = whole roasted soybeans. 
Table 11. Least square means for production and composition of milk from lactating dairy cows fed diets containing different rumen-protected soy products.

\begin{tabular}{|c|c|c|c|c|c|c|}
\hline \multirow[b]{2}{*}{ Item } & \multicolumn{4}{|c|}{ Treatment $^{1}$} & \multirow[b]{2}{*}{ SEM } & \multirow[b]{2}{*}{$P>\mathrm{F}$} \\
\hline & SSBM & ESBM & NSBM & WRSB & & \\
\hline Milk, kg/d & $20.5^{\mathrm{b}}$ & $22.6^{\mathrm{ab}}$ & $25.0^{\mathrm{a}}$ & $22.5^{\mathrm{ab}}$ & 2.0 & 0.04 \\
\hline $3.5 \% \mathrm{FCM},{ }^{2} \mathrm{~kg} / \mathrm{d}$ & $22.2^{\mathrm{c}}$ & $25.2^{\mathrm{b}}$ & $28.3^{\mathrm{a}}$ & $24.2^{\mathrm{b}}$ & 2.0 & 0.04 \\
\hline \multicolumn{7}{|l|}{ Fat } \\
\hline$\%$ & 4.04 & 4.24 & 4.36 & 4.05 & 0.38 & 0.51 \\
\hline $\mathrm{kg} / \mathrm{d}$ & $0.82^{\mathrm{c}}$ & $0.94^{\mathrm{b}}$ & $1.08^{\mathrm{a}}$ & $0.90^{\mathrm{b}}$ & 0.06 & 0.001 \\
\hline \multicolumn{7}{|l|}{$\mathrm{CP}$} \\
\hline$\%$ & 3.62 & 3.63 & 3.65 & 3.46 & 0.12 & 0.21 \\
\hline $\mathrm{kg} / \mathrm{d}$ & $0.74^{\mathrm{c}}$ & $0.81^{b}$ & $0.90^{\mathrm{a}}$ & $0.78^{c}$ & 18.6 & 0.04 \\
\hline \multicolumn{7}{|l|}{ True protein } \\
\hline$\%$ & 3.43 & 3.44 & 3.47 & 3.28 & 0.13 & 0.23 \\
\hline $\mathrm{kg} / \mathrm{d}$ & $0.70^{\mathrm{b}}$ & $0.77^{\mathrm{b}}$ & $0.86^{\mathrm{a}}$ & $0.73^{\mathrm{b}}$ & 0.06 & 0.005 \\
\hline \multicolumn{7}{|l|}{$\mathrm{TS}$} \\
\hline$\%$ & 13.2 & 13.2 & 13.5 & 12.9 & 0.42 & 0.21 \\
\hline $\mathrm{kg} / \mathrm{d}$ & $2.71^{\mathrm{b}}$ & $2.96^{\mathrm{b}}$ & $3.38^{\mathrm{a}}$ & $2.89^{\mathrm{b}}$ & 0.23 & 0.01 \\
\hline MUN, ${ }^{3} \mathrm{mg} / \mathrm{dL}$ & 16.7 & 16.4 & 16.1 & 16.7 & 2.40 & 0.94 \\
\hline
\end{tabular}

${ }^{\mathrm{a}, \mathrm{b}, \mathrm{c}}$ Values within the same row with uncommon superscripts are different $(P<0.05)$. Pairwise comparisons were calculated using the appropriate standard error.

${ }^{1} \mathrm{ESBM}=$ Expeller soybean meal; NSBM = heated, xylose-treated soybean meal; SSBM = solvent-extracted soybean meal; and WRSB = whole roasted soybeans.

${ }^{2} 3.5 \% \mathrm{FCM}=0.4324$ (kilograms of milk) +16.216 (kilograms of fat).

in the profile of EAA that exit the rumen is accounted for by the individual EAA content of RUP and the contribution of RUP to the intestinal supply of NAN. Because differences in the EAA composition among soy protein sources were small (Table 2 ), it is reasonable to expect that significant improvements in the intestinal supply of EAA, particularly of Lys and Met, would be achieved only if the contribution of NANMN to the passage of NAN to the duodenum is remarkably increased. As previously indicated, the proportion of the ruminal outflow of NAN contributed by NANMN was not affected significantly by treatments, which provides an explanation for the lack of significant responses in the postruminal supply of Lys and Met in response to the addition of ESBM, NSBM, or WRSB to the SSBMbased diet.

\section{Production of Milk and Milk Composition}

Yields of milk and 3.5\% FCM were highest for NSBM, intermediate for ESBM and WRSB, and lowest for SSBM, although differences in milk production were significant only between SSBM and NSBM (Table 11). The concentration of fat, CP, true protein, TS, and urea $\mathrm{N}$ were not affected by the source of soy protein. The yield of milk components, however, paralleled changes in milk production. That is, the yield of fat, $\mathrm{CP}$, true protein, and TS were highest for NSBM, intermediate for ESBM and WRSB, and lowest for SSBM. However, differences in the daily output of true protein and TS were not significant among SSBM, ESBM, and WRSB.
In a summary of 37 comparisons (Ipharraguerre and Clark, 2005), it was estimated that replacing SSBM with rumen-protected soy products significantly increased the yield of milk but did not affect the production of CP and fat. It should be noted, however, that the magnitude of the response in milk output $(+2.7 \%)$ that was estimated in that review was 12 to 4 times smaller than the responses obtained in this experiment (i.e., $+21.9,10.3$, and $9.8 \%$ for NSBM, ESBM, and WRSB, respectively). In another summary of the literature, Santos et al. (1998) reported that increasing the RUP content of SSBM-based diets with rumen-protected soy products significantly increased milk yield in 6 of 29 comparisons but significantly decreased milk protein percentage in 8 of the 29 comparisons. Using data from 13 treatment comparisons between SSBM and WRSB, Grummer and Rabelo (2000) estimated that feeding WRSB to dairy cows in research trials increased the yields of milk and FCM on average by 1.5 and $2.3 \mathrm{~kg} /$ $\mathrm{d}$ but decreased milk protein content by 0.10 percentage units. Similar lactational responses were estimated by these authors for 12 comparisons between SSBM and extruded soybeans. Although the positive milk and FCM responses elicited by rumen-protected soy products in this experiment are consistent with previous research, the magnitude of these effects was considerably larger than expected. For this reason, and because of the limited number of cows that were involved in this study, caution is recommended in extrapolating these data to other situations. 


\section{CONCLUSIONS}

Replacing SSBM with rumen-protected soy products in the diet of lactating dairy cows sustained DMI and did not alter the extent, percentage, and site of OM and starch digestion. Compared with SSBM, soy supplements of reduced rumen degradability decreased the molar proportion of isobutyrate and valerate as well as the concentration of $\mathrm{NH}_{3} \mathrm{~N}$ (ESBM and NSBM) in ruminal fluid. The NSBM and WRSB treatments increased, and ESBM tended to increase, the intestinal supply of NANMN without depressing the ruminal outflow of microbial N. However, increases in the ruminal outflow of NANMN elicited by these RUP sources were not sufficiently large to result in significant improvements in the postruminal supply of Met and Lys.

These results suggest that replacing a portion of SSBM with ESBM, NSBM, or WRSB may increase the quantity of feed protein that reaches the small intestines of dairy cows. However, significant improvements in the supply of previously reported limiting AA for milk production, particularly of Met, should not be expected. To accomplish this goal, it seems that these rumen-protected soy products must be combined with other RUP sources and (or) rumen-protected AA that complement their EAA profile.

\section{ACKNOWLEDGMENTS}

The authors thank Vita Plus Corporation (Madison, WI) for donating the WRSB.

\section{REFERENCES}

Allison, M. J. 1978. Production of branched-chain volatile fatty acids by certain anaerobic bacteria. Appl. Environ. Microbiol. 35:872-877.

Association of Official Analytical Chemists. 1990. Official Methods of Analysis. Vol. I, 15th ed. AOAC, Arlington, VA.

Bremner, J. M., and D. R. Keeney. 1965. Steam distillation methods for determination of ammonium, nitrate, and nitrite. Anal. Chim. Acta 32:485-495.

Chaney, A. L., and E. P. Marbach. 1962. Modified reagents for determination of urea and ammonia. Clin. Chem. 8:130-132.

Clark, J. H., T. H. Klusmeyer, and M. R. Cameron. 1992. Microbial protein synthesis and flows of nitrogen fractions to the duodenum of dairy cows. J. Dairy Sci. 75:2304-2323.

Cleale, R. M., IV, R. A. Britton, T. J. Klopfenstein, M. L. Bauer, D. L. Harmon, and L. D. Satterlee. 1987. Induced non-enzymatically browning of soybean meal. II. Ruminal escape and net portal absorption of soybean protein treated with xylose. J. Anim. Sci. 65:1319-1326.

Cotta, M. A., and J. B. Russell. 1982. Effects of peptides and amino acids on efficiency of rumen bacterial protein synthesis in continuous culture. J. Dairy Sci. 65:226-234.

Firkins, J. L., and F. L. Fluharty. 2000. Soy products as protein sources for beef and dairy cattle. Pages 182-214 in Soy in Animal Nutrition. J. K. Drackley, ed. FASS, Savoy, IL.

Grummer, R. R., and E. Rabelo. 2000. Utilization of whole soybeans in dairy cattle diets. Pages 215-237 in Soy in Animal Nutrition. J. K. Drackley, ed. FASS, Savoy, IL.
Harstad, O. M., and E. Prestlokken. 2000. Effective rumen degradability and intestinal indigestibility of individual amino acids in solvent-extracted soybean meal (SBM) and xylose-treated SBM (SoyPass ${ }^{\circledR}$ ) determined in situ. Anim. Feed Sci. Technol. 83:31-47.

Ipharraguerre, I. R., and J. H. Clark. 2005. Impacts of the source and amount of crude protein on the intestinal supply of nitrogen and performance of lactating dairy cows. J. Dairy Sci. 88(E. Suppl.):E22-E37.

Jenkins, T. C. 1993. Lipid metabolism in the rumen. J. Dairy Sci. 76:3851-3863.

Kartchner, R. J., and B. Theurer. 1981. Comparison of hydrolysis methods used in feed, digesta, and fecal starch analysis. J. Agric. Food Chem. 29:8-11.

Knapp, D. M., R. R. Grummer, and M. R. Dentine. 1991. The response of lactating dairy cows to increasing levels of whole roasted soybeans. J. Dairy Sci. 74:2563-2572.

Littell, R. C., G. A. Milliken, W. W. Stroup, and R. D. Wolfinger. 1996. SAS System for Mixed Models. SAS Inst., Inc., Cary, NC.

Lobley, G. E. 2002. Protein turnover-What does it mean for animal production? Pages 1-15 in Proc. Symp. Amino Acids: Milk, Meat, and More. H. Lapierre and D. R. Ouellet, ed. Can. Soc. Anim. Sci., Quebec, Canada.

Ludden, P. A., and M. J. Cecava. 1995. Supplemental protein sources for steers fed corn-based diets: I. Ruminal characteristics and intestinal amino acid flows. J. Anim. Sci. 73:1466-1475.

Ludden, P. A., J. M. Jones, M. J. Cecava, and K. S. Hendrix. 1995. Supplemental protein sources for steers fed corn-based diets: II. Growth and estimated metabolizable amino acid supply. J. Anim. Sci. 73:1476-1486.

Mabjeesh, S. J., A. Arieli, I. Bruckental, S. Zamwell, and H. Tagari. 1996. Effect of type of protein supplementation on duodenal amino acid flow and absorption in lactating dairy cows. J. Dairy Sci. 79:1792-1801.

Maiga, H. A., D. J. Schingoethe, and J. E. Henson. 1996. Ruminal degradation, amino acid composition, and intestinal digestibility of the residual components of five protein supplements. J. Dairy Sci. 79:1647-1653.

Mansfield, H. R., and M. D. Stern. 1994. Effects of soybean hulls and lignosulfonate-treated soybean meal on ruminal fermentation in lactating dairy cows. J. Dairy Sci. 77:1070-1083.

McCarthy, R. D., Jr., T. H. Klusmeyer, J. L. Vicini, J. H. Clark, and D. R. Nelson. 1989. Effects of source of protein and carbohydrate on ruminal fermentation and passage of nutrients to the small intestine of lactating cows. J. Dairy Sci. 72:2002-2016.

Miller, T. K., and W. H. Hoover. 1998. Nutrient analyses of feedstuff including carbohydrates. Anim. Sci. Rep. 1, West Virginia Univ., Morgantown.

Mohamed, O. E., L. D. Satter, R. R. Grummer, and F. R. Ehle. 1988. Influence of dietary cottonseed and soybean on milk production and composition. J. Dairy Sci. 71:2677-2688.

Moore, S. 1963. On the determination of cystine as cysteic acid. J. Biol. Chem. 238:235-237.

National Research Council. 2001. Nutrient Requirements of Dairy Cattle. 7th rev. ed. Natl. Acad. Sci., Washington, DC.

Orias, F., C. G. Aldrich, J. C. Elizalde, L. L. Bauer, and N. R. Merchen. 2002. The effects of dry extrusion temperature of whole soybeans on digestion of protein and amino acids by steers. J. Anim. Sci. 80:2493-2501.

Overton, T. R., M. R. Cameron, J. P. Elliott, J. H. Clark, and D. R. Nelson. 1995. Ruminal fermentation and passage of nutrients to the duodenum of lactating cows fed mixtures of corn and barley. J. Dairy Sci. 78:1981-1998.

Pires, A. V., M. L. Eastridge, and J. L. Firkins. 1996. Roasted soybeans, blood meal, and tallow as sources of fat and ruminally undegradable protein in the diets of lactating cows. J. Dairy Sci. 79:1603-1610.

Reynal, S. M., and G. A. Broderick. 2003. Effects of feeding dairy cows protein supplements of varying ruminal degradability. J. Dairy Sci. 86:835-843.

Reynal, S. M., G. A. Broderick, S. Ahvenjärvi, and P. Huhtanen. 2003. Effect of feeding protein supplements of differing degradability 
on omasal flow of microbial and undegraded protein. J. Dairy Sci. $86: 1292-1305$.

Rulquin, H., and R. Vérité. 1993. Amino acid nutrition in dairy cows: Production effects and animal requirements. Pages 55-77 in Recent Advances in Animal Nutrition. P. C. Garnsworthy and D. J. A. Cole, ed. Nottingham University Press, Nottingham, UK.

Santos, F. A. P., F. E. P. Santos, C. B. Theurer, and J. T. Huber. 1998. Effects of rumen-undegradable protein on dairy cow performance: A 12-year literature review. J. Dairy Sci. 81:3182-3213.

SAS. 2000. SAS System for Windows. Release 8.1 (TS1 MO). SAS Inst., Inc., Cary, NC.

Stern, M. D., K. A. Santos, and L. D. Satter. 1985. Protein degradation in rumen and amino acid absorption in small intestine of lactating dairy cattle fed heat-treated whole soybeans. J. Dairy Sci. 68:45-56.

Supelco, Inc. 1975. GC Separation of VFA C2-C5. Tech. Bull. 749D. Supelco, Inc., Bellefonte, PA.
Tice, E. M., M. L. Eastridge, and J. L. Firkins. 1993. Raw soybeans and roasted soybeans of different particle sizes. 1. Digestibility and utilization by lactating cows. J. Dairy Sci. 76:224-235.

Van Soest, P. J., J. B. Robertson, and B. A. Lewis. 1991. Methods for dietary fiber, neutral detergent fiber, and nonstarch polysaccharides in relation to animal nutrition. J. Dairy Sci. 74:35833597.

Williams, C. H., D. J. David, and O. Iismaa. 1962. The determination of chromic oxide in faeces samples by atomic absorption spectrophotometry. J. Agric. Sci. 59:381-385.

Windschitl, P. M., and M. D. Stern. 1988. Evaluation of calcium lignosulfonate-treated soybean meal as a source of rumen protected protein for dairy cows. J. Dairy Sci. 71:3310-3322.

Zinn, R. A., and F. N. Owens. 1986. A rapid procedure for purine measurement and its use for estimating net ruminal protein synthesis. Can. J. Anim. Sci. 66:157-166. 